\title{
Woody woodpecker enjoys soft drinks: the blond-crested woodpecker seeks nectar and pollinates canopy plants in south-eastern Brazil ${ }^{1}$
}

\author{
Márcia A. Rocca ${ }^{2,4}$, Marlies Sazima ${ }^{2}$ \& Ivan Sazima ${ }^{3}$ \\ Biota Neotropica v6 (n2)-http://www.biotaneotropica.org.br/v6n2/pt/abstract?short-communication+bn02606022006 \\ Date Received 08/31/2005 \\ Revised 04/05/2006 \\ Accepted 05/31/2006 \\ ${ }^{2}$ Departamento de Botânica, Caixa Postal 6109, Universidade Estadual de Campinas, 13083-970 Campinas, São Paulo, Brasil \\ ${ }^{3}$ Departamento de Zoologia e Museu de História Natural, Caixa Postal 6109, Universidade Estadual de Campinas, \\ 13083-970 Campinas, São Paulo, Brasil (www.unicamp.br) \\ ${ }^{4}$ Corresponding author. Tel: +55-19-3788 6170; fax: +55-19-3788 6374; roccamarcia@yahoo.com.br
}

\begin{abstract}
Rocca, M.A.; Sazima, M. and Sazima, I. Woody woodpecker enjoys soft drinks: the blond-crested woodpecker seeks nectar and pollinates canopy plants in south-eastern Brazil. Biota Neotrop. May/Aug 2006, vol. 6, no. 2, http:// www.biotaneotropica.org.br/v6n2/pt/abstract?short-communication+bn02606022006. ISSN 1676-0611
\end{abstract}

Insects are the staple diet of woodpeckers, but some species also habitually feed on fruits. A few woodpecker species are recorded as flower visitors for nectar intake. We report here on the blond-crested woodpecker (Celeus flavescens) taking nectar from flowers of two canopy species, Spirotheca passifloroides (Bombacaceae) and Schwartzia brasiliensis (Marcgraviaceae), in the Atlantic forest of south-eastern Brazil. Spirotheca passifloroides blooms for three months in the austral winter, whereas $S$. brasiliensis blooms for two months in the summer. Flowers of both species produce large amounts of dilute nectar. Celeus flavescens visits several flowers per plant touching the anthers and stigmas with its head and throat, and thus acts as a pollen vector. We suggest that woodpeckers may be more frequent flower visitors than previously thought, and that feeding on ripe fruits may be a simple behavioural step for the origin of nectar feeding by Neotropical woodpeckers.

Key words: Celeus flavescens, Picidae, Spirotheca passifloroides, Bombacaceae, Schwartzia brasiliensis, Marcgraviaceae, ornithophily

\section{Resumo}

Rocca, M.A.; Sazima, M. and Sazima, I. Um pica-pau que aprecia bebidas doces: o joão-velho procura néctar e poliniza plantas de dossel no Sudeste do Brasil. Biota Neotrop. May/Aug 2006, vol. 6, no. 2, http://www.biotaneotropica.org.br/ v6n2/pt/abstract?short-communication+bn02606022006. ISSN 1676-0611

Insetos formam a dieta básica dos pica-paus, porém algumas espécies também se alimentam habitualmente de frutos e poucas espécies procuram flores para tomar néctar. Registramos aqui o joão-velho ou pica-pau-de-cabeça-amarela (Celeus flavescens) ao tomar néctar de flores em duas espécies de plantas do dossel, Spirotheca passifloroides (Bombacaceae) e Schwartzia brasiliensis (Marcgraviaceae), em Mata Atlântica do sudeste do Brasil. Spirotheca passifloroides floresce por três meses no inverno, ao passo que S. brasiliensis floresce ao longo de dois meses no verão. As flores de ambas as espécies produzem néctar abundante e diluído. Celeus flavescens visita várias flores por planta, tocando as anteras e os estigmas com a cabeça e o pescoço, assim agindo como polinizador. Sugerimos que visitas de pica-paus a flores sejam mais freqüentes do que o suposto e que se alimentar em frutos maduros seria um passo comportamental simples para a origem da tomada de néctar por pica-paus neotropicais.

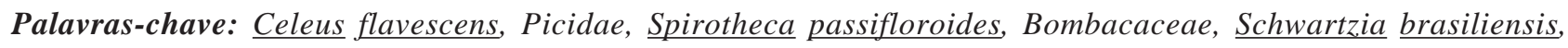
Marcgraviaceae, ornitofilia

\footnotetext{
${ }^{1}$ Dedicated to Benjamin Luz, Ivan Soler and Marcial Cotes (climbers ), and to Talita Fontoura ( responsible for the Field Course on
} Canopy Ecology) for training climbing abilities to MAR 


\section{Introduction}

Woodpeckers (Picidae) feed mostly on insects, although some species also feed habitually on ripe fruits (Winkler \& Christie 2002). However, there are a few records of these part time frugivores visiting flowers and feeding on nectar (e.g. Kattan 1988, Molina-Freaner \& Eguiarte 2003). Among the woodpeckers recorded visiting flowers for nectar are species of the genus Melanerpes, which are also among the most prone to forage on fruits and berries (Winkler \& Christie 2002).

While studying canopy flowers visited by birds in the Atlantic forest in southeast Brazil, we recorded the blond-crested woodpeckers (Celeus flavescens) foraging for nectar of two plant species. We present here floral features of these plants, the woodpecker behaviour while on flowers, and comment on possible origin of nectarivory in Picidae.

\section{Material and Methods}

The blond-crested woodpecker (Figure 1) is widely distributed throughout eastern South America, from lower Amazon in Brazil to Misiones in Argentina (Sick 1997, Winkler \& Christie 2002). With $27 \mathrm{~cm}$ in total length, it feeds primarily on ants and termites, and also forages on ripe fruits (Sick 1997, Winkler \& Christie 2002).

Field observations were made in the Atlantic forest reserve at the Núcleo Sete Barras of the Parque Estadual

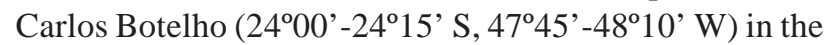
southern part of São Paulo, southeast Brazil. The study site is at about 50-100 m a.s.l.; its climate is of type Cfa of Köppen. The coastal Atlantic forest in São Paulo has an average annual rainfall of up to $2000 \mathrm{~mm}$ and there is no well defined dry season, even during so-called dry months (May to August) when monthly rainfall is below $200 \mathrm{~mm}$ (Nimer 1977).

All canopy plant species believed to be visited by birds were observed from January 2003 to February 2005. Access to the canopy plants was gained with climbing equipment (see Perry \& Williams 1981, Whitacre 1981). Canopy level, blooming period, and bird visitors were recorded for each plant species. Floral biology was studied following procedures outlined in Dafni (1992). Nectar sugar concentration and accumulated volume were measured from randomly chosen bagged flowers with a pocket refractometer and a microlitre syringe, respectively, by the end of the morning. Four focal plants of Spirotheca passifloroides (Bombacaceae) were watched during eight non-consecutive days at the flowering peak and at the end of bloom, totalling about 15 hours. Additionally, four focal plants of Schwartzia brasiliensis (Marcgraviaceae) were watched during six non-consecutive days at the flowering peak, totalling about 10 hours.

\section{Results}

The blond-crested woodpecker was recorded visiting two out of three forest plant species whose flowers were visited by birds other than hummingbirds (the third one is a species of the loranthaceous genus Psittacanthus, from a total of 60 species recorded for the studied birdflower assemblage). Spirotheca passifloroides bloomed in the austral winter for three months (June-August in 2003; May-July in 2004). The height of the plants in the canopy varied from 13 to $30 \mathrm{~m}$. Some plants bore about 180 open flowers per day. The red flowers are large and their nectar is easily accessible (Figure 2 and Table 1). Schwartzia brasiliensis bloomed in the summer for two months (January-February in 2004; December-January in 2004/2005). The height of the plants in the canopy varied from 8 to $20 \mathrm{~m}$. Some plants bore up to 10 inflorescences. The small, red flowers are arranged in brush-like inflorescences, and the extrafloral nectaries are a contrasting deep purple (Figure 3). The cup-like nectaries have wide openings (Table 1), and thus are easily accessible for several bill types and sizes (see Sazima et al 1993).

Only female blond-crested woodpeckers were recorded exploiting these flowers, but we were unable to tell whether the woodpecker was the same or another individual during the visits. We recorded the woodpecker on the flowers of S. passifloroides (Figure 4) three times in two consecutive days at the end of the blooming period. The visits were made at a plant $22 \mathrm{~m}$ high in the canopy. While taking nectar from the flowers the woodpecker contacted the stamens and stigmas, pollen being placed on its forehead and crown. Visits to S. brasiliensis flowers were recorded once on a plant $15 \mathrm{~m}$ high in the canopy. The woodpecker perched on the inflorescence axis and took nectar from several nectaries in a row. While taking nectar the woodpecker received pollen on its head and throat.

\section{Discussion}

Both S. passifloroides and S. brasiliensis occur in the forest canopy, and thus their flowers have the potential to be visited by birds other than hummingbirds in the studied area (see also Toledo 1977). The flowers of both species are typically ornithophilous (sensu Faegri \& van der Pijl 1980, Endress 1994), although their nectar is much more dilute than that of several species of hummingbird-pollinated plants (e.g. Buzato et al. 2000, Araujo \& Sazima 2003, MAR pers. obs.). Dilute and copious nectar is characteristic of ornithophilous flowers visited by birds other than hummingbirds (see review in Nicolson \& Fleming 2003). Ten species of perching birds and eight species of hummingbirds were recorded as visitors of Schwartzia brasiliensis by Sazima et al (1993), who noted that passerines and not hummingbirds are the main pollinators of this plant in southeast Brazil. Spirotheca brasiliensis is also visited by a di- 
verse assemblage of 11 bird species including hummingbirds, perching birds, and woodpeckers (MAR pers. obs.).

One suggestion for the origin of flower-visiting by birds is that fruit-eating species began to destructively eating flowers, whereas another idea deals with woodpeckers' habit to feed on sap flowing from holes in plants (cf. Faegri \& van der Pijl 1980). As for Neotropical woodpeckers, the former idea seems more likely than the latter, since species in the genera Melanerpes (Kattan 1988, Ruiz et al. 2000) and Celeus habitually feed on ripe fruits and berries (Sick 1997, Winkler \& Christie 2002). Moreover, sap-feeding remains to be recorded for these two genera in the Neotropics. Indeed, Melanerpes uropygialis is known for its nectar feeding on flowers of several plants, including those of cacti and agaves in scrubland and deserts (Winkler \& Christie 2002, Molina-Freaner \& Eguiarte 2003), and M. formicivorus is recorded taking nectar from two species of Bombacaceae, Ochroma lagopus and Spirotheca sp. in lower montane wet forest (Kattan 1988).

We suggest that moving from feeding on fruit juice to taking nectar from flowers is a relatively simple behavioural step for the woodpeckers. The long, protrusible tongue of these birds, provided with barbs or brush-like tips (Winkler \& Christie 2002) may be as adequate to extract juice from ripe fruits as to sip nectar from flowers. As Celeus is another woodpecker genus known as having a "sweet tooth” (Sick 1997, Winkler \& Christie 2002), visits to flowers would be expected for species within this genus. Indeed, a brief account on C. grammicus acting as a pollinator of Symphonia globulifera (Clusiaceae), an Amazonian tree species up to $20 \mathrm{~m}$ tall, is available in a popular journal (Pivetta 2003). We expect that additional records of flowervisiting woodpeckers in the Neotropics will likely to be uncovered by further studies on forest canopy plants, especially for species of such fruit-feeding genera as Celeus and Melanerpes (Sick 1997).

\section{Acknowledgements}

To Maikon P. dos Santos for help in the field; Iara Bressan for technical help; T. Fontoura and T. B. Breier for lending some climbing gear; Edson Endrigo for free use of Figure 1; Luís Fábio Silveira for the confirmation of the identity of Celeus grammicus; João Paulo Krajewski for the enhancement of Figure 4; the staff of the Parque Estadual Carlos Botelho/IF for the logistics and help in the field. This study was partially supported by the State of São Paulo Research Foundation (FAPESP) within the BIOTA/FAPESP - The Biodiversity Institute Program (www.biota.org.br) and the "Parcelas Permanentes" project, as well as by CAPES, CNPq, FAEP/FUNCAMP/Unicamp and The Nature Conservancy of Brazil. This study is part of MAR Doctoral thesis at the Programa de Pós-Graduação em Biologia Vegetal, Departamento de Botânica, Universidade Estadual de Campinas, São Paulo.

\section{References}

ARAUJO, A.C. \& SAZIMA, M. 2003. The assemblage of flowers visited by hummingbirds in the "capões" of Southern Pantanal, Mato Grosso do Sul, Brazil. Flora 198:427-435.

BUZATO, S., SAZIMA, M. \& SAZIMA, I. 2000. Hummingbird-pollinated floras at three Atlantic Forest Sites. Biotropica 32(4b):824-841.

DAFNI, A. 1992. Pollination ecology - A practical approach. Oxford University Press, Oxford.

ENDRESS, P.K. 1994. Diversity and evolutionary biology of tropical flowers. Cambridge University Press, Cambridge.

FAEGRI, K. \& VAN DER PIJL, L. 1980. The principles of pollination ecology. 2 ed. Pergamon Press, New York.

KATTAN, G. 1988. Food habits and social organization of acorn woodpeckers in Colombia. The Condor 90:100-106.

MOLINA-FREANER, F. \& EGUIARTE, L.E. 2003. The pollination biology of two paniculate agaves (Agavaceae) from northwestern Mexico: contrasting roles of bats as pollinators. Am. J. Bot. 90(7):1016-1024.

NICOLSON, S.W. \& FLEMING P.A. 2003. Nectar as food for birds: the physiological consequences of drinking dilute sugar solutions. Plant Syst. Evol. 238:139-153.

NIMER, E. 1977. Climatologia da região sudeste do Brasil. Rev. Bras. Geog. 34:3-48.

PERRY, D.R. \& WILLIAMS, J. 1981. The tropical rain forest canopy: a method providing total access. Biotropica 13(4):283-285.

PIVETTA, M. 2003. Encontros fugazes. Pesquisa FAPESP 90:36-39.

RUIZ, A., SANTOS, M. \& CAVELIER, J. 2000. Estudio fenológico de Cactáceaes en el enclave seco de la Tatacoa, Colombia. Biotropica 32(3):397-407.

SAZIMA, I., BUZATO, S. \& SAZIMA, M. 1993. The bizarre inflorescence of Norantea brasiliensis (Marcgraviaceae): visits of hovering and perching birds. Bot. Acta 106:507-513.

SICK, H. 1997. Ornitologia Brasileira. 2 ed. Editora Nova Fronteira, Rio de Janeiro.

TOLEDO, V.M. 1977. Pollination of some rain forest plants by non-hovering birds in Veracruz, Mexico. Biotropica 9:262-267.

WHITACRE, D.F. 1981. Additional techniques and safety hints for climbing tall trees, and some equipment and information sources. Biotropica 13(4):286-291.

WINKLER, H. \& CHRISTIE, D.A. 2002. Family Picidae (Woodpeckers). In Handbook of the birds of the world (J. del Hoyo; A. Elliot \& J. Sargatal, eds.). Lynx Edicions, Barcelona. v. 7, Jacamars to woodpeckers, p.296-555. 
Note added in proof: Celeus and Melanerpes are two genera for which visits to flowers are documented in the Neotropics (Kattan 1988, Ruiz et al. 2000, Winkler \& Christie 2002, Molina-Freaner \& Eguiarte 2003, present paper). Since these two genera are nested in distinct clades within the Picidae, Celeus within the Malarpicini and Melanerpes within the Dendropicini (Benz et al. in press), we suggest that flower-visiting behaviour arose independently and more than once during the woodpeckers' evolution. The apparently exclusive insect-eating habits of the basalmost sister clades (Benz et al. in press) seem to strengthen our suggestion.

BENZ, B.W., ROBBINS, M.B. \& PETERSON, A.T. In press.

Evolutionary history of woodpeckers and allies (Aves: Picidae): Placing key taxa on the phylogenetic tree. Molecular Phylogenetics and Evolution.

Title: Woody woodpecker enjoys soft drinks: the blondcrested woodpecker seeks nectar and pollinates canopy plants in south-eastern Brazil.

Authors: Rocca, M.A.; Sazima, M. and Sazima, I.

Biota Neotropica, Vol. 6 (number 2): 2006

http://www.biotaneotropica.org.br/v6n2/pt/ abstract?short-communication+bn02606022006

Date Received 08/31/2005 - Revised 04/05/2006

Accepted 05/31/2006

ISSN 1676-0611 


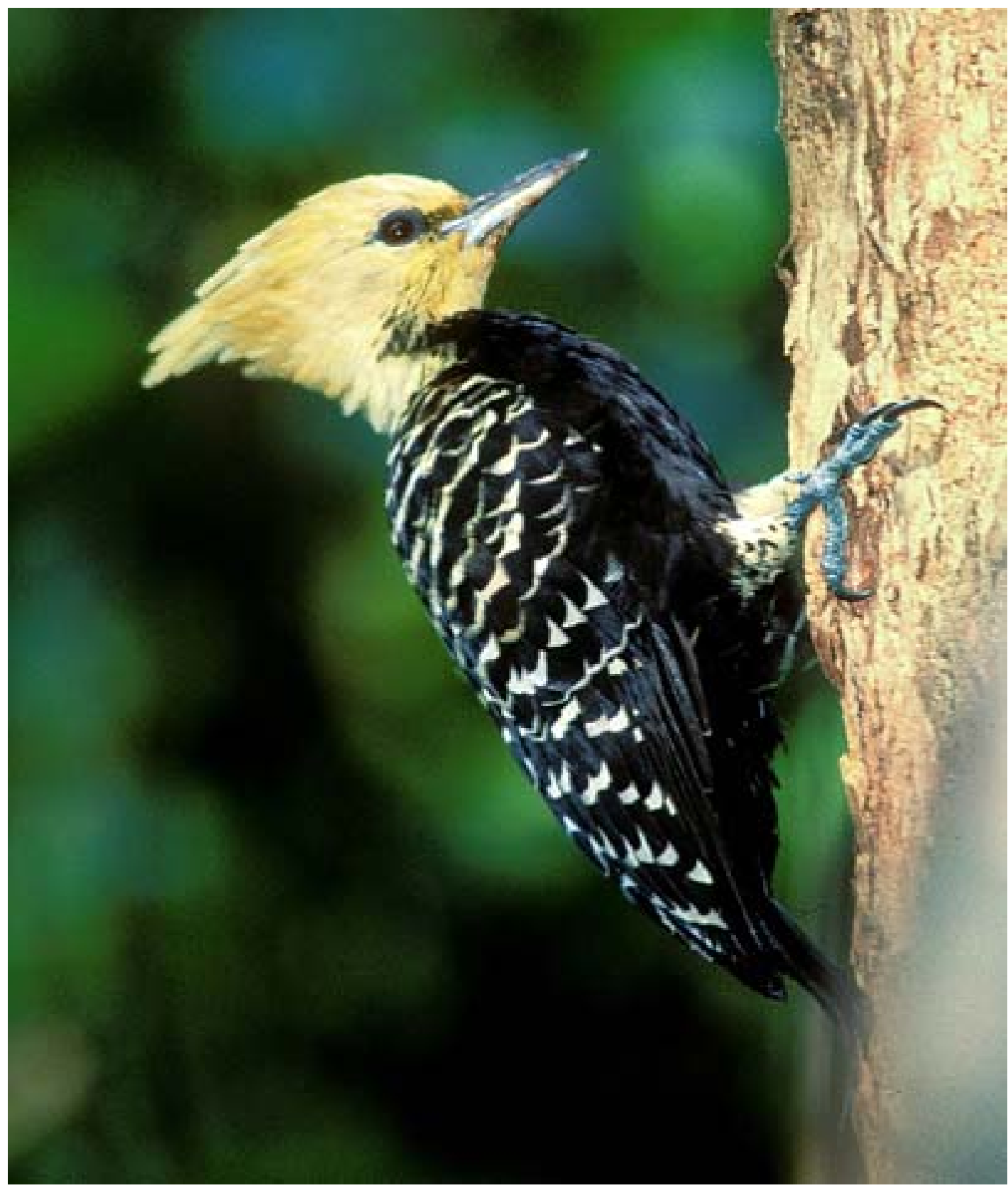

Figure 1 - A blond-crested woodpecker female (Celeus flavescens) foraging for insects on a tree trunk. Note dirt on bill. Photo (CEdson Endrigo. 


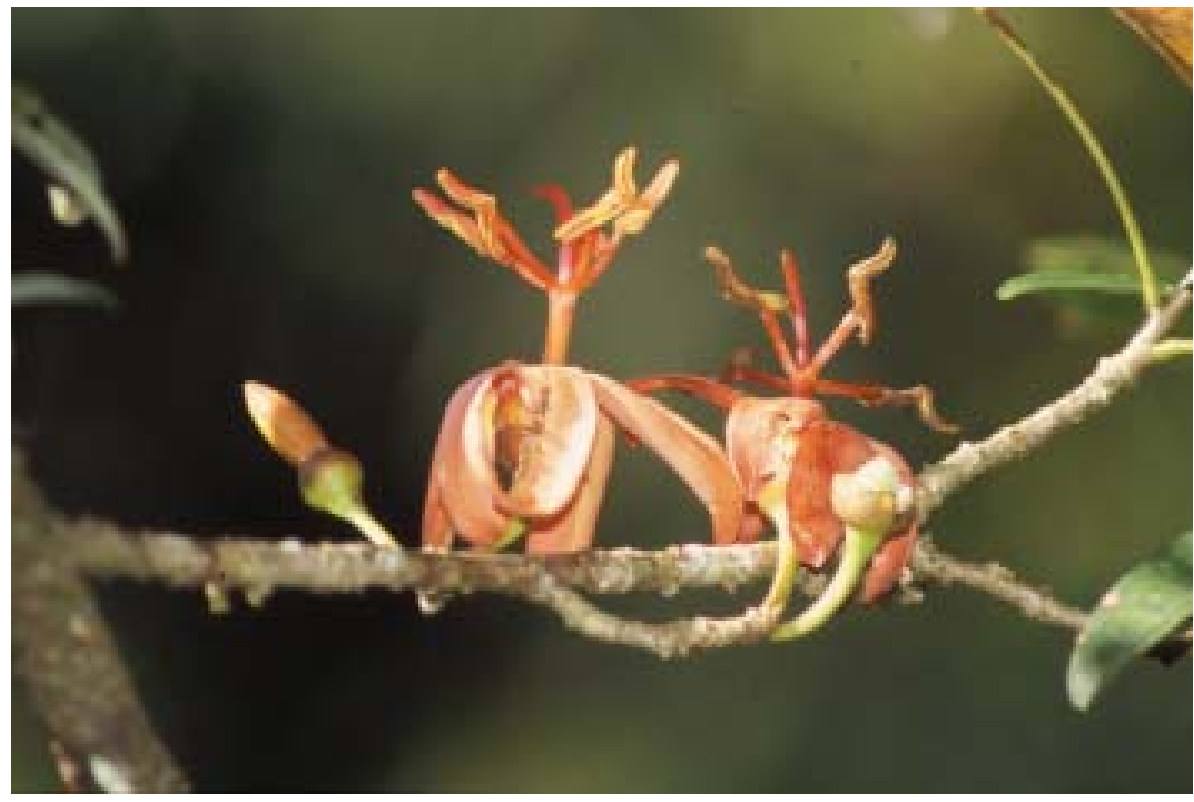

Figure 2 - Two fully open Spirotheca passifloroides flowers. Note position of the stigma and stamens. 
Rocca, M.A.; Sazima, M.; Sazima, I. - Biota Neotropica, v6 (n2) - bn02606022006

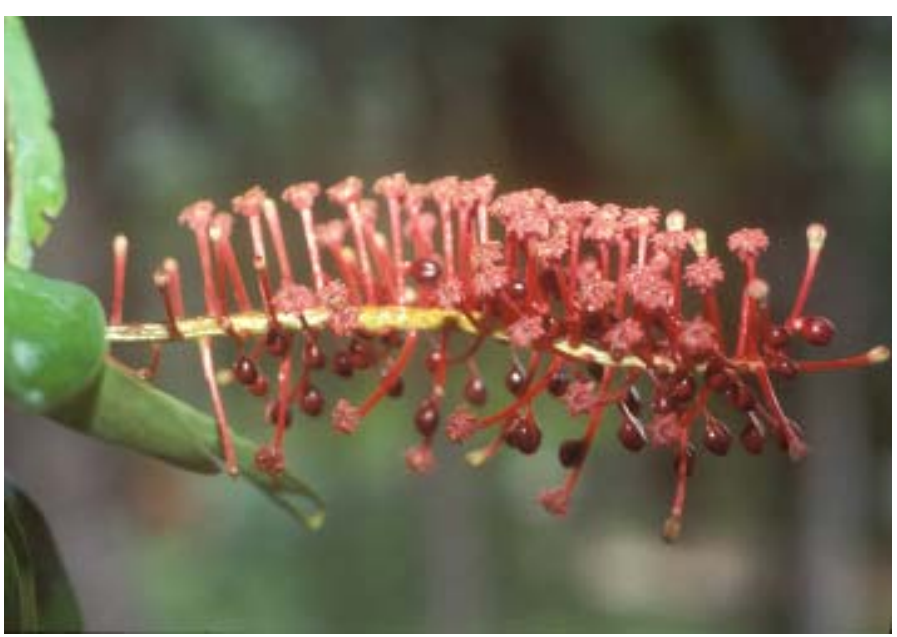

Figure 3 - An inflorescence of Schwartzia brasiliensis. Note purple extrafloral nectaries. 


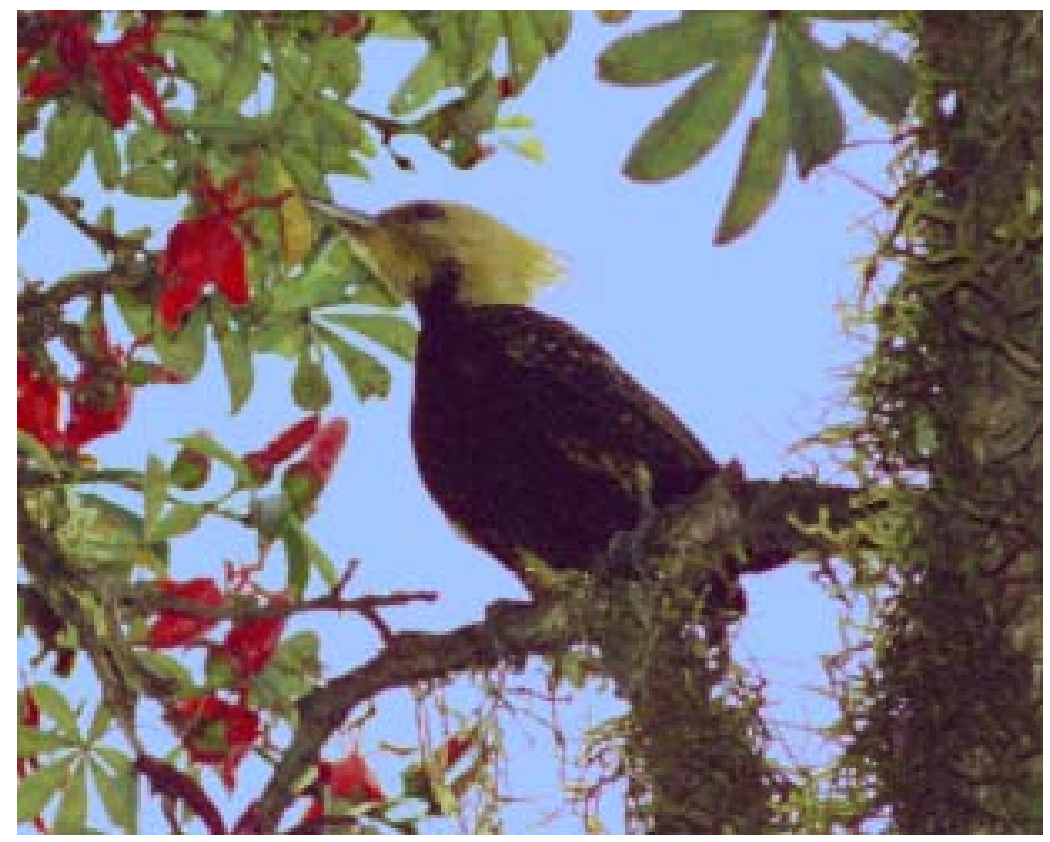

Figure 4 - A blond-crested woodpecker female (Celeus flavescens) about to take nectar from a flower of Spirotheca passifloroides. Flowers reddened during the original photo enhancement (compare with Figure 2). 
Table 1: Floral features of Spirotheca passifloroides and Schwartzia brasiliensis at the Parque Estadual Carlos Botelho, Sete Barras, São Paulo, south-eastern Brazil. $N=30$ flowers for all measurements except for nectar of S. passifloroides $(N=15$ flowers).

\begin{tabular}{lcccccc}
\hline Species & Colour & Shape & Length $(\mathrm{mm})$ & Diameter $(\mathrm{mm})$ & Volume $(\mu \mathrm{l})$ & Concentration $(\%)$ \\
\hline S. passifloroides & red & brush & $48.4 \pm 6.7$ & $10.9 \pm 1.7$ & $141.9 \pm 78.4$ & $6.0 \pm 1.2$ \\
S. brasiliensis & red \& purple & $\operatorname{dish}^{1}$ & $29.0 \pm 2.8^{2}$ & $6.1 \pm 0.7^{1}$ & $34.3 \pm 13.9$ & $4.6 \pm 2.0$ \\
\hline
\end{tabular}

${ }^{1}$ Dish flowers in brush-like inflorescences.

${ }^{2}$ Extrafloral nectaries measurements. 